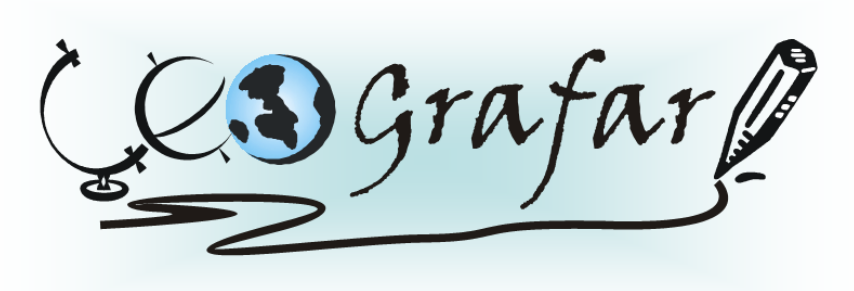

Revista Eletrônica do Programa de Pós-Graduação em Geografia - UFPR

\title{
O HOMEM, A NATUREZA E A CIDADE: PLANEJAMENTO DO MEIO FÍSICO ${ }^{1}$
}

Prof. Dr. Carlos Augusto de Figueiredo Monteiro

\section{APRESENTAÇÃO}

Este texto foi especialmente elaborado como suporte à Conferência que seria proferida na abertura do VIII Congresso Brasileiro de Arborização Urbana. Pela sua extensão, sua leitura ultrapassaria certamente os 60 minutos previstos pelo regulamento do congresso. Além do que jamais seria capaz de uma "leitura" perante um auditório. Prefiro sempre a expressão oral direta que, malgrado o caráter coloquial, o perigo de saltar ou esquecer alguns fatos, além de outros inconvenientes, pode ganhar a atenção do auditório pela espontaneidade.

Na exposição oral faz-se necessária a mostra de figuras ilustrativas do que o discurso vai tratando. Assim a verbalização é para ser acompanhada de 20 figuras esboçadas, com o recurso de transparências em retro-projeção. Esta diferença entre o planejado e o oferecido resulta que a exposição oral será obrigatoriamente mais curta do que a descartada leitura do texto. Na realidade, a terceira parte contida no texto não chegou a ser proferida na exposição oral, ficando os dez tópicos ali apresentados para uma possível discussão na mesa redonda subseqüiente.

Quanto às ilustrações apresentadas na exposição oral (20 figuras) elas dificultariam muito uma provável publicação, tanto pelo número elevado quanto pelo fato de serem, em sua maioria, coloridas.

Assim sendo, o texto não faz referência direta às figuras. Embora valorizassem sobremodo a compreensão, as condicionantes editoriais impediriam sua utilização.

\footnotetext{
${ }^{1}$ Conferência proferida no VIII Congresso Brasileiro de Arborização Urbana. São Paulo, 13-18 setembro de 2004.
} 
Deste modo, há que considerar as sensíveis diferenças entre o que está formalizado no texto e o que pôde ser dito e ilustrado na conferência.

\section{A CIDADE COMO REFLEXO DA RELAÇÃO HOMEM-NATUREZA - Limitações do Planejamento}

Como geógrafo fui sempre fascinado pelas relações Homem-Natureza. A atividade acadêmica universitária, vinculada a disciplina de Geografia Física, contribuiu para que se me rotulassem como "Físico", rotulação essa que sempre rejeitei. Como divisão do trabalho didático assumi disciplinas mais ligadas à ênfase na natureza. A eleição da "climatologia" como campo de investigação viria acentuar ainda mais aquele rótulo. Contudo, quem conhece a obra que deixei, sabe que sempre estive preso ao caráter unitário da Geografia. Mesmo na pesquisa dos climas, interessaram-me, sobretudo, as relações do comportamento atmosférico com a atividade do homem. Inclusive na abordagem dos climas urbanos sobre o que me esforcei em oferecer as bases de um suporte teórico capaz de englobar o comportamento atmosférico na cidade, inteiramente relacionado às diferentes facetas da organização "natural" e o desempenho social definidor da vida urbana.

Nestas últimas etapas de minha produção geográfica procurei projetar os frutos de uma pequena (mas significativa) experimentação interdisciplinar no campo do "planejamento urbano" em concepções mais amplas sobre o fenômeno urbano.

Em dois momentos (MONTEIRO, 1993 e 2002) atrevi-me a mobilizar o mito de Édipo - consagrado por Freud a interpretação psicanalítica no "complexo de Édipo" - no seu contexto político de mito do urbano, em sua vinculação do homem em face da cidade. Apoiado nas tragédias de Sófocles, extraí o jogo de contrastes entre o jovem Édipo (Édipo Rei), vencedor da esfinge à entrada de Tebas e aquele do Édipo velho e cego, a entrada de Atenas (Édipo em Colono). No primeiro caso, do jovem Édipo, resultou-lhe a conquista de Tebas implicada no infortúnio de tornar-se parricida e incestuoso. No segundo, do Édipo velho, cego, alquebrado, ele almeja, tão somente, a acolhida de Atenas no seu bosque de Colono para ser sepulcro.

Poder-se-iam extrair daí duas atitudes - a conquista e o merecimento - na relação do homem com a forma de concentração social implantada num dado trato de natureza que é a 
cidade. Creio eu que esses dois modos podem, dentro de uma variadíssima gama, apontar atitudes do homem em face do viver aglomerado na cidade. Inclusive se lhe é outorgada a função de planejar a cidade. Ocorre-me, agora, acrescentar um comprovante sério da grande dificuldade que é aquela do Homem encontrar o seu lugar de morada - aglomerado socialmente num dado espaço natural - que é aquele expresso nas UTOPIAS.

O mito da Atlântida no diálogo Críticas, de Platão, bem poderá servir como um dos pioneiros mitos urbanos. Cidade esplendorosa, harmoniosa no centro de um território que ela organiza e domina (polariza). Uma espécie de ilha da fantasia em meio a um oceano de natureza já alterada, de campos já cultivados, espaços ora de hostilidade ora de doçura. Cidade instauradora de um espaço de harmonia em meio a tensões das ações recíprocas dos diferentes elementos. Mas, acima de tudo, mera lembrança de um continente submerso, desaparecido, distanciado passado daquele presente.

Desde que o homem é um animal gregário, social, todos os lugares ideais, não existentes mas desejados ardentemente, as utopias, se não todas mas a grande maioria, são visualizadas como cidades. Assim é na República de Platão (428-348 a.C.); na Cidade de Deus de Santo Agostinho (354-430 d.C.); na Utopia de Thomas Morus (1478-1535).

A cidade tem um passado histórico muito vasto e não é o caso de recordá-lo aqui nesta palestra, dirigida ao "planejamento". Evolução natural, espontânea e intervenções lanejadoras (ligadas estas às ações políticas fortes de poderes absolutos) podem ser observadas intercaladamente. Importa, acima de tudo, considerar o volume e intensidade das mudanças que têm ocorrido nestes últimos tempos, de tal modo revestidas de complexidade, o que faz com que a necessidade de "planejamento" seja levada em consideração apesar de suas inegáveis limitações e dificuldades.

Cabe admitir que, a partir da segunda metade do século XIX e durante o século XX, sobretudo após a segunda grande guerra mundial (1939-1945), o grau e o volume das mudanças foram altamente significativos. Sem querer simplificar a real complexidade do fenômeno, poder-se-á creditar à industrialização e aos transportes e comunicações os fatores responsáveis mais decisivos nestas mudanças. O primeiro, pela atração populacional e adensamento de edificações, aumentando a complexidade dos espaços urbanos, tanto em estrutura (morfologia) quanto nas funções (processos). O progresso nos meios de transporte passando da locomoção a pé, pelo recurso a animalia (hipocirculação), à roda e a motorização crescente em velocidade. A evolução das cidades na antiguidade, os grandes acréscimos 
ocorridos na Idade Média, as sensíveis alterações pós-Renascença até os tempos Modernos registraram, tanto em ritmo quanto em volume, intensidade bem modesta em relação àqueles desse passado mais recente até nossos dias.

É fato reconhecido que a cidade é o centro do espaço humanizado e que, num mundo simbolicamente organizado, o papel da cidade é aquele de conferir uma imagem ordenada do universo. Ela seria a expressão daquilo que o homem, com seu arbítrio e capacidade organizadora, conquistara ao caos da natureza, ordenando o cosmos que ela pretende ser. A cidade é antes de tudo o testemunho do seu poder de veto sobre a natureza.

Entre a cidade - espaço ordenado pelo homem - e a natureza hostil: florestas, escarpas, montanhas e vales profundos, etc. o homem gerou um espaço intermediário que é o campo, domínio de sua cultura selecionando, da "desordem" da natureza, as plantas úteis à sua alimentação e os animais domesticáveis tanto para auxiliá-lo no trabalho como também para a sua nutrição.

O campo, embora pertencente ao espaço da cultura, ocupa uma posição “complementar", subordinada. Ele se vincula a um estatuto ambíguo, intermediário à floresta - radicalmente estranha à criação humana - e aquele espaço humanizado, artificial que é a "cidade".

Dessa temática das relações Homem-Natureza ocorre-me evocar Mircea Eliade que em sua obra

$\underline{\text { Imagens e Símbolos }}{ }^{2}$ comenta que:

\begin{abstract}
"As sociedades arcaicas e tradicionais concebem o mundo circundante como um microcosmo. Após os limites deste mundo fechado, começa o domínio do desconhecido, do não-formado. De uma parte há o espaço cosmizado, posto que habitado e organizado - de outra parte, ao exterior desse espaço familiar, existe a região desconhecida e assustadora dos demônios, das larvas, dos mortos, dos estrangeiros: em uma palavra, o caos, a morte, a noite. [...] Todo microcosmo, toda região habitada, aquilo que se poderia considerar um "centro", isto é, um lugar sagrado por excelência.É lá, neste centro, que o sagrado se manifesta de uma maneira total.” (M. Eliade, op.cit. p.47).
\end{abstract}

No que concerne à dita civilização ocidental, foi na Idade Média, com a geração dos burgos e das cidades que a condição de centralidade urbana no espaço geográfico tornou-se

\footnotetext{
${ }^{2}$ Refiro-me a edição francesa. ELIADE, Mircea: “Images et Symboles" - Paris, Gallimard, 1952.
} 
bem característico. Embora crescendo de volume no Renascimento e Século XVII chega ao século XVIII ainda como um microcosmo no qual o indivíduo é, tanto espacial quanto temporalmente, situado à sua dimensão. Não esqueçamos o fato de que é neste século que o homem começa a sentir a força da urbanização e os negativos da aglomeração e acrescenta à trama do urbano os primeiros parques e jardins públicos.

Até o século XIX os aglomerados urbanos, a despeito da textura morfológica complexa, imposta pelo seu crescimento, ainda constituem morfologias equilibradas, o que se vincula ao fato de que o valor das distâncias ainda está ligado à medida do passo do homem. Os grandes acréscimos e transformações que se produziram ao longo do Século XX, embora ligadas à implosão populacional e as perturbações e reviravoltas nos valores econômicos e sociais, como também ao triunfo irremediável da energia, o vetor mais diretamente responsável tem sido aquele do transporte. Os centros urbanos industrializados ligaram-se rapidamente pelas redes ferroviárias. Da circulação pedestre e hipomóvel chegou-se a automotora, congestionando ruas e estradas.

Com o crescimento das cidades, em grandeza morfológica e complexidade funcional, inverteu-se aquele sistema coerente de "oposições cidade-campo". As ressonâncias pejorativas dirigidas a natureza e laudatórias à cidade inverteram-se. Os espaços urbanizados cresceram em tamanho e complexidade. Os espaços naturais, em vias de crescente retração, são agora valorizados como alívio às agruras da vida urbana. São valorizados como espaços de lazer e turismo (importante indústria em franco desenvolvimento). Os antagonismos do sagrado (bem) e profano (mal) inverteram-se. E o campo, aquele intermediário complementar? Além de alterado pelo progresso tecnológico do agronegócio capitalista e as profundas repercussões sociais, geradora de evasão do campo para aumentar os problemas sociais das cidades (implosão demográfica, inchação urbana) o campo vê-se afetado pela multiplicação dos núcleos urbanos e pelos processos de "conurbações". O campo vem se revelando, também, como complemento da natureza, gerador de hotéis-fazenda onde a população citadina vai inteirar-se das virtudes saudáveis e bucólicas da vida rural. E essa ligação já facilitada pelos progressos nos transportes acentua-se mais ainda com aqueles nas comunicações.

A aventura humana na face da Terra, em apenas cinco ou seis gerações, teve o seu quadro de integração espacial-temporal deslocado do nível local ao planetário. Os progressos nas comunicações pelo telégrafo, telefone, foram suplantados pelos progressos da eletrônica, 
com os atuais microcomputadores, "e-mails", telefonia celular, e as novidades que se sucedem a cada dia na maior rapidez.

A Geografia, como não podia deixar de ser, sempre dispensou especial atenção ao estudo das cidades que se vem mostrando, cada vez mais, como a morada por excelência do homem na face da Terra. Dentre inúmeras razões, duas delas respondem por esse interesse: de um lado pela concentração populacional, organização social e dinamização econômica; de outro porque os espaços urbanizados são aqueles onde mais avultam as mudanças (derivações, transfigurações) que o homem inflige ao meio natural. Consoante o crescente aumento na complexidade urbana, sobretudo no pós-guerra, amplia-se o interesse pela Geografia Urbana. Numa avaliação feita entre geógrafos anglofonos, a temática urbana era a preponderante ${ }^{3}$ nos anos sessenta.

Além da complexidade e do crescente desconforto observado nas grandes cidades americanas a segunda guerra mundial na Europa acarretara a destruição de muitas cidades, o que resultou na preocupação de que a tarefa de reconstrução estivesse vinculada ao planejamento. Grandes foram os esforços dispensados no Reino Unido, inclusive entre os geógrafos, dentre os quais se destacou Duddley Stamps, no planejamento das "new towns" britânicas. Berlim, destruída em cerca de $70 \%$ de sua área, ainda hoje - passado meio século é um canteiro de obras aberto a um planejamento mais racional (sobretudo depois da junção dos dois setores em que esteve separada pelo muro) aberta a variados experimentos em urbanismo.

A propósito destas profundas "mudanças" ocorridas no universo urbano, evoco aqui uma consideração que, a propósito de tais mudanças, foi feita por Le Corbusier:

“(...) uma ruptura brutal, única nos anais da história vem de deslocar, em três quartos de século, toda a vida social do ocidente de seu quadro relativamente tradicional e notavelmente enquadrado à geografia."

Vale a pena refletir sobre o que o grande arquiteto-urbanista quis significar com esse “enquadramento geográfico". Imagino que se trata do fato de que até a metade do Século XX, a realidade urbana era analisada na Geografia então vigente numa abordagem equilibrada

\footnotetext{
${ }^{3}$ Refiro-me a uma avaliação efetuada pelo geógrafo Roads Murphy inserida na coletânea organizada por MIKESEL, M.W. (1973) intitulada GEOGRAPHERS ABROAD, num artigo rotulado "Geographic Study of Climate", inserido às paginas 94-109.
} 
entre o embasamento natural e a edificação social. Estudar geograficamente a cidade significava entender as articulações entre sítio e posição. O primeiro significado dado ao espaço da superfície terrestre sobre o qual se assentava (ou implantava) a cidade. A essa vinculação local juntava-se aquela visão exterior, numa projeção regional, pela qual se articulavam não apenas as relações da cidade com os acidentes naturais como com as relações econômicas. Enquanto o sítio servia, entre outras coisas, a classificar as cidades numa tipologia de assentamento - cidades acrópoles, portuárias, etc. etc. a posição projetava-se cada vez mais às injunções econômicas da vida de relações. O estudo de redes urbanas (a partir dos anos cinqüenta foi grandemente embalado pelos estudos econômicos de polarização, centroperiférica, etc. etc.. Esta preocupação um tanto equilibrada entre as variáveis naturais e sócioeconômicas estão muito bem retratadas no manual Urban Geography de autoria do britânico Griffith Taylor ${ }^{4}$ (1949) obra essa que na visão dos geógrafos "do humano" foi ironizada com a pecha de ser "o último suspiro do determinismo geográfico".

Generalizando - pelo menos em termos do mundo dito ocidental, centrado pela Europa e Estados Unidos da América - a cidade foi se tornando complexa, transformando os seus antigos méritos em problemas cujas soluções nem sempre são fáceis, tornando-se aquela madre que nos engendra e nos devora (na imagem do poeta mexicano Octavio Paz). Espaço de mistério, onde as forças naturais representadas pela esfinge - híbrido maléfico do reino animal, - de muitas Tebas a serem conquistadas, desafiando-nos a que as transformemos naquele espaço de paz e tranqüilidade no qual adentramos pelo bosque sagrado de Colono, voltado ao reino vegetal, alcançando aquela Atenas onde merecemos viver em paz.

A cidade que ora nos desafia é uma complexa mistura (ou combinação?) de natureza e cultura numa caprichosa elaboração de uma ordem simbólica, a partir de uma humanização do espaço e do tempo. Espaço cenário que nos abrigue e nos proteja na dinâmica de nossa movimentação quotidiana num tempo cada vez mais precioso.

Ao englobar os fundamentos naturais que esboçaram os primeiros elementos de um

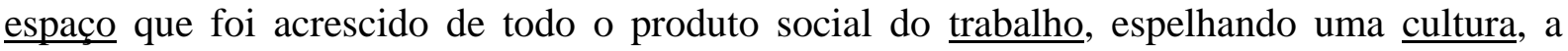
cidade engloba ação política (moral e ética), mediação estética, conciliando o útil funcional ao belo, numa congregação altamente acumulada de conflitantes interesses, o que requer a

\footnotetext{
${ }^{4} \mathrm{O}$ título completo da obra de Griffith Taylor é: Urban Geography: a study of site, evolution pattern and classification in villages, towns and cities. - London \& Co., Ltd - 1949.
} 
vigência de uma pacto social, regido por uma ordem jurídica que assegure adequação e equidade ao que é produzido pela técnica.

Com isso tudo a cidade é um desafio a pluridisciplinaridade. Não há um só dentre os diferentes ramos dos saberes que possa dar conta da realidade urbana. Ela requer e desafia a congregação interdisciplinar. Aqui estamos nós, em um evento dirigido a presença da vegetação na cidade e de vários diferentes domínios acadêmicos e profissionais, para discutir a cidade. E isto numa metrópole que é um verdadeiro laboratório uma vez que encerra desde o alto esplendor ao mais baixo degrau da miséria.

Para melhor expressar essa complexidade e a necessidade imperiosa de recorrer aos diferentes campos do saber talvez seja associar a cidade à lingüística. Já se tem consciência de que a idéia de linguagem foi altamente enriquecida pela semiótica ${ }^{5}$. A cidade pode ser encarada como uma imagem que pode ser decifrada, decodificada. Em trabalho anterior já tive ensejo de dar à cidade uma leitura geográfica (MONTEIRO, 1996) ${ }^{6}$ tomando leitura no sentido emprestado a semiótica, considerando-a:

\begin{abstract}
“... como objeto complexo, passível de decifração, decodificação ou leitura, constituindo um "texto não verbal", algo que se grava no espaço. Aliás em múltiplos espaços já que o fenômeno urbano é um contexto onde eles se superpõem, acumulam, integram (ou desintegram) em diferentes modos e graus. Há portanto que lidar com "signos" de várias procedências: do geográfico ao social, do econômico, pelo cultural, promovendo a existência de vários signos imbricados, compondo tanto uma metalinguagem (geral) quanto várias microlinguagens (setoriais)".
\end{abstract}

MONTEIRO, 1996 (apoiado em FERRARA, 1988) op.cit. p.70-71.

Isso posto, cumpre agora inserir a tarefa de planejar, ou seja, elaborar um plano, proceder a um planejamento na cidade. $\mathrm{O}$ planejamento é algo tido como indispensável à gestão. Mas, se a "cidade" é algo complexo, o planejar não o é menos. Planejar assenta em prever e prover: prever conseqüências e prover recursos materiais. Além disso, planejar

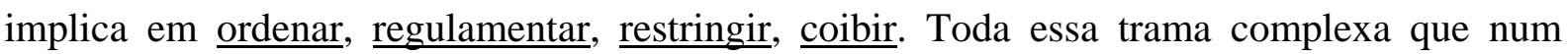
aglomerado socialmente heterogêneo implicará em favorecimento a uns, contrariedade a outros.

\footnotetext{
${ }^{5}$ Ver a propósito FERRARA, Lucrecia d'Alessio "Ver a cidade: cidade, imagem, leitura". São Paulo, Nobel, 1988 (80pp).

${ }^{6}$ MONTEIRO, C.A. de Figueiredo - "O Significante Ambiental em Sobrados e Mocambos: uma leitura geográfica"in FONSECA, Edson Nery da (Organizador) - SOBRADOS E MUCAMBOS: Entendimento e Interpretação - Recife - Fundação Joaquim Nabuco, Ed. Massangana, 1996.
} 
O filósofo Karl Popper em sua obra A "Sociedade Aberta e seus Inimigos" é céptico quanto ao "planejamento". Num dado momento ele idaga "Quem planeja os planejadores? (Who plans the planners?). E a prática do planejamento nas sociedades "fechadas" nos experimentos socialistas, embora tenha revelado méritos quando dirigida ao processo econômico, (planos qüinqüenais) não foram bem sucedidos quando dirigidos aos resultados urbanos. Nem mesmo a URSS, nos tempos duros de Stalin, conseguiu produzir cidades perfeitas. E o que dizer do planejamento urbano nos países capitalistas, na vigência da propriedade privada, das grandes diferenças de classes sociais distanciadas em dominadores (mestres) e dominados (escravos)?

Em toda a evolução histórica do fenômeno urbano encontramos dinâmicas diferenciadas dos processos (urbanização) e configurações morfológicas que oscilam mais para o espontâneo do que para o dirigido. É certo que há exemplos variados de orientações problemáticas e intervenções corretivas nos diferentes países, em variadas culturas.

Após as primeiras revoluções industriais na Europa os problemas urbanos se agravaram e há belos exemplos de grandes intervenções corretivas que traçam as bases do que viria a ser o "urbanismo". Os exemplos mais clássicos são aqueles de Paris, nas reformas do Barão Haussmann? (1853-70) e aquele da Viena "fin de Siècle", com a grande obra do Ringstrasse promovida por Camillo Sitte e Otto Wagner (1873). Quanto aos Estados Unidos da América, com sua alta industrialização e desenvolvimento nos transportes, este país criou uma vasta rede urbana com grandes cidades, fornecendo "modelos" de morfologia urbana ${ }^{8}$ fartamente estudadas tanto por geógrafos quanto por outros especialistas. (Lembremo-nos de Lewis Munford e Jane Jacobs).

Voltando-nos ao quadro brasileiro, constatamos que, em suas dimensões continentais e variedade de definições regionais, a extensa rede urbana oferece aos estudiosos um leque bem variado de exemplos e problemas. A visão histórica dos processos de urbanização mostra exemplos variados de evolução de cidades em suas gêneses portuárias, $\underline{\text { mineradoras, feirantes }}$ (agrícolas e pecuárias) até aquelas que, mais recentemente, foram "criadas" (e

\footnotetext{
${ }^{7}$ Deve-se reconhecer que a gigantesca obra de melhorias urbanas empreendidas em Paris pelo Barão de Haussmann foram possíveis pelo suporte autocrático do III Império, da França sob Napoleão III. Quanto a Viena, após a grande obra de canalização do Danúbio, que inundava freqüentemente a cidade, a obra do Ringstrasse foi sustentada por habitantes prósperos e profissionais liberais, e desacompanhada de qualquer benefício social às classes pobres.

${ }^{8}$ Como o modelo CONCÊNTRICO proposto por Burgess, inspirado em CHICAGO.
} 
conseqüentemente "planejadas") para a função primordialmente administrativa de capitais de Estados.

Logo pensamos em Brasília (1960) cujo “planejamento urbano” após quarenta anos de existência já nos oferece uma boa oportunidade de avaliação entre as propostas iniciais e os fatos que a realidade foi impondo. Sobretudo a consideração do sempre presente dualismo de nossa formação social: o plano piloto (dos mestres) e as cidades satélites (dos "coadjuvantes" que ficam à margem) que representam $2 / 3$ da população da capital federal. Belo Horizonte, que já ultrapassou o centenário, amplia essa possibilidade de avaliação cujos resultados preliminares já podem registrar que, do que foi planejado, apenas um décimo da população atual da capital mineira se enquadraria nela. Goiânia, cujo "batismo cultural" ocorreu em 1942, é um outro valioso caso de avaliação9.

A instituição da obrigatoriedade de "planos diretores" para as cidades brasileiras data dos anos sessenta, do período da intervenção militar. Mais adiante, em 1973, seriam definidas as primeiras regiões metropolitanas (RMs) que de onze foram recentemente ampliadas para um número bem mais elevado. A obrigatoriedade de elaboração de planos diretores urbanos foi uma oportunidade para um considerável treinamento profissional muito embora sua aplicabilidade prática resultasse de pequena a nula. Normalmente eram propostos por escritórios do eixo Rio- São Paulo; ou das capitais mais adiantadas que elaboravam um

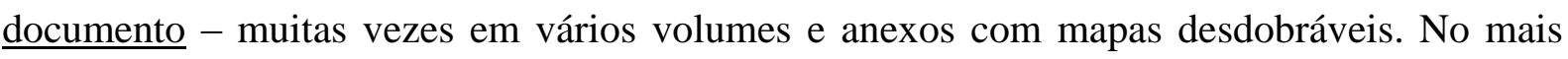
das vezes não passaram de troféus, colocados à mesa dos prefeitos municipais aos quais, sem poder compreendê-los, servia, pelo menos, para exibi-los às visitas ilustres.

Os casos apontados ficam completamente desprezíveis quando consideramos o nosso caso mais sério, ou seja, aquele referente à nossa Grande Metrópole Nacional, esta São Paulo que nos acolhe. Nem precisarei deter-me para comentar a gravidade que o caso assume nesta grande metrópole. Bastaria evocar a atualidade e o aceso dos debates registrados na mídia

\footnotetext{
${ }^{9}$ Deixo de mencionar aqui os casos pioneiros em "criação" de capitais, as nordestinas TERESINA, no Piauí (1852) e Aracaju, Sergipe, um pouco mais adiante, porquanto no meado do século XIX as concepções de "urbanismo" eram muito embrionárias. Teresina partiu de um simples traçado em tabuleiro de xadrez, à margem do rio Parnaíba, - suposta artéria natural de circulação dos recursos - para sanar a excessiva centralidade sertaneja da velha Oeiras.
} 
nestes dois últimos anos a propósito do mais recente ${ }^{10}$ Plano Diretor de Desenvolvimento Integrado do Município de São Paulo aprovado a 23 de agosto de $2002^{11}$.

E diante de tanta divergência avulta a importância de eventos como esse que ora estamos principiando, reunindo vários profissionais e estudiosos da cidade sob os seus mais variados aspectos e viezes do saber. E no meio de tanta diversidade o que caberia a um geógrafo trazer para vocês em termos da consideração do "meio físico". Em vez dessa expressão reducionista melhor seria substituí-la por "Presença da Natureza na Cidade do Homem". Num momento histórico em que, na grande crise que atravessamos, merece um foco especial, juntam-se aqui, as sendas da Questão Urbana e da Questão Ambiental. Uma prova cabal dessa relação íntima é que esta palestra será seguida por uma mesa redonda focalizando ATLAS AMBIENTAIS das cidades de Porto Alegre e São Paulo.

$\mathrm{Na}$ medida de minhas possibilidades, do meu passado de pesquisador e de atual estudioso e consumidor da produção dos colegas mais jovens militantes ativos tanto na aplicação profissional quanto na pesquisa acadêmica, além dessa (talvez dispensável) introdução cabe-me ilustrar o tema central - planejamento do meio natural - com uma experiência por mim vivida numa equipe de planejamento urbano, justamente no nível de uma circunstancia que me parece adequada para ilustrá-lo. Trata-se do caso da elaboração de um plano para a implantação de uma cidade, vinculada a uma atividade econômica prevista num projeto de exploração de um recurso natural de mérito na Amazônia.

\section{UM CASO DE PLANEJAMENTO URBANO A PARTIR DA IMPLANTAÇÃO DO NÚCLEO INICIAL - Barcarena, Pará (1979-2003)}

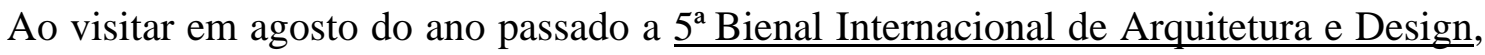
no Ibirapuera, em São Paulo, a ala destinada aos arquitetos urbanistas convidados especiais, na mostra oferecida por Joaquim Guedes e Associados, deparei-me com painéis referentes ao Planejamento Urbano de Barcarena, Estado do Pará (Figura 1), encontrando meu nome no

\footnotetext{
${ }^{10}$ Este plano, elaborado na gestão da Prefeita Marta Suplicy, iniciado m 2001, foi antecedido por aqueles elaborados nas gestões Jânio Quadros (1986-1988) e Figueiredo Ferraz (1971-1973).

${ }^{11}$ Há um fortíssimo material coletável na mídia. Além daqueles que mencionei no texto A Cidade Desencantada (MONTEIRO, 2002) apontaria a entrevista do Professor Flávio Villaça, da FAU-USP dada à Folha de São Paulo, na edição de Domingo, 1o de setembro de 2002, Caderno C página 16 e, no mesmo jornal, edição de 21 de julho de 2004, a matéria de toda a página 4 do Caderno C, com o cabeçalho "Para Urbanistas, Plano Diretor não tem foco", confrontando opiniões de seis destacados urbanistas de São Paulo.
} 
meio dos membros da equipe envolvida na elaboração do mesmo. Confesso que, agora, aposentado da USP - afastado diretamente das lides do ensino, pesquisa e assessorias técnicas - relembrar aquela experiência realizada em 1979 causou-me uma grande emoção. Ao lado das lembranças daquele convívio agradável com o arquiteto Joaquim Guedes e sua equipe, no trabalho de campo e nas discussões de gabinete, assaltou-me uma grande curiosidade sobre o destino daquele projeto. Passados 24 anos, um significativo quarto de século, qual teria sido o destino daquela cidade?

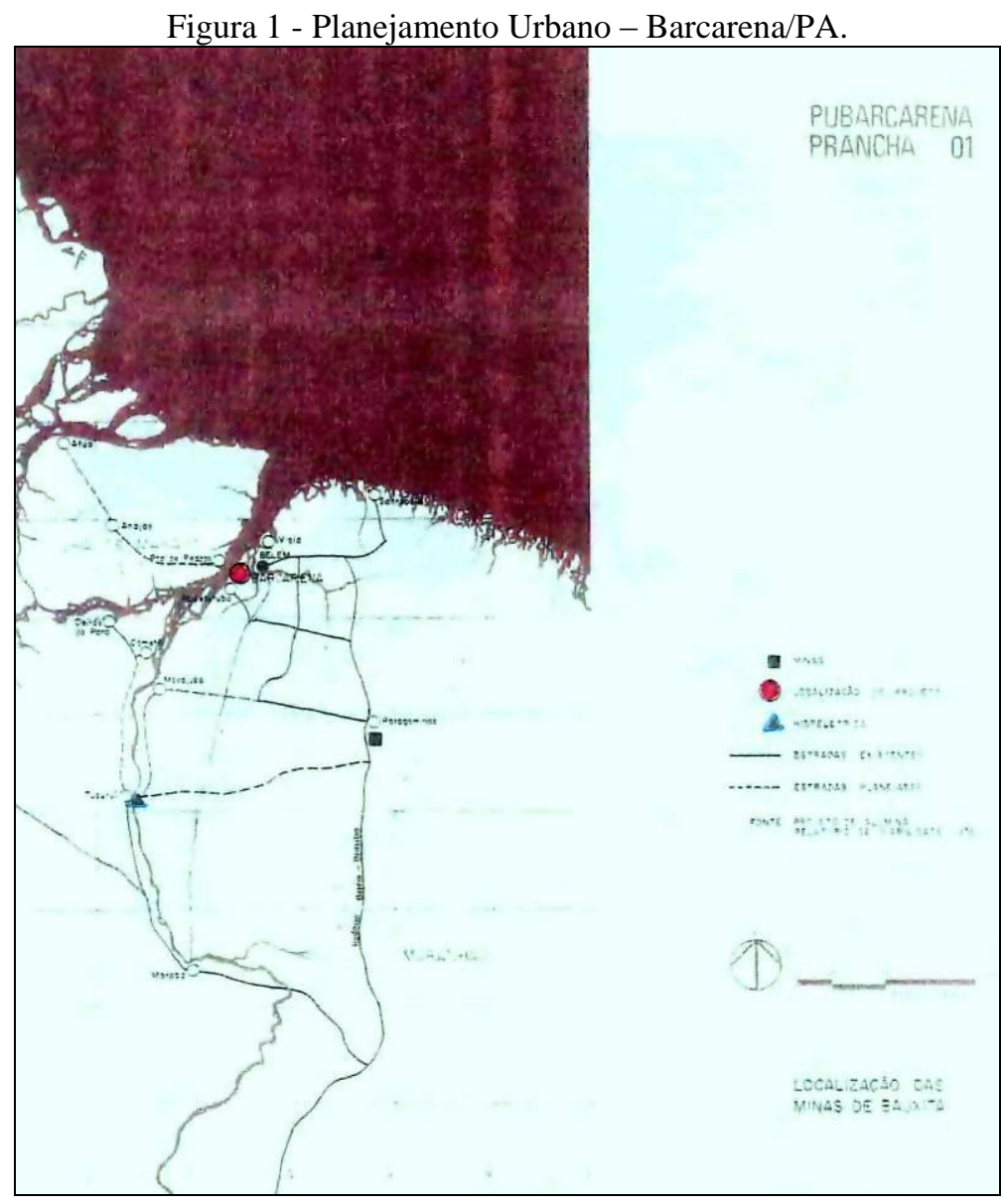

Planejada naquele programa de desenvolvimento econômico da Amazônia Brasileira, segundo as diretrizes da intervenção militar - norteada pela ideologia da segurança nacional e da efetiva ocupação da nossa Amazônia, - cujo desenvolvimento econômico previa a criação de "pólos de desenvolvimento" em torno da exploração de recursos naturais de mérito, o projeto da Barcarena paraense ligava-se à instalação de um complexo industrial de beneficiamento da bauxita do vale do rio Trombetas, associado a uma instalação portuária adequada a recepção do minério e a exportação da "beneficiada" alumina, incluindo a 
implantação de um núcleo urbano para assentar dirigentes, técnicos e população necessária à implementação daquele projeto.

Joaquim Guedes, como urbanista, já vinha acumulando experiência em projetos de implantação e planejamento urbano dentre os quais, se não falha a memória, o Plano Diretor de Boa Vista, Rondônia. Ao convidar-me para aquele projeto, dava-se continuação a uma experiência anterior dirigida a Marabá, também no Pará, vale do Tocantins. Guedes declaroume que, no afã de conduzir seus associados numa verdadeira prática de interdisciplinaridade", a experiência tida com a inclusão de geógrafo lhe parecera animadora. Se o projeto de Marabá não teve aprovação, aquele de Barcarena foi mais bem sucedido e, conseqüentemente, implantado.

No momento seguinte procurei acompanhar pela imprensa as notícias sobre o referido projeto e sua implantação. A associação a capitais e técnica japonesas, o complexo industrial da Albrás - Alunorte (a não sei que mais outras) ligava-se ao projeto da Hidrelétrica do TUCURUÍ, $300 \mathrm{~km}$ ao sul, principiando por um gasto de $60 \mathrm{mil} \mathrm{Kw}$, mas previsto para 580 mil (duas vezes o consumo da capital Belém, naquele momento). Em 1985, durante o Governo Sarney, deu-se a inauguração da Albrás ${ }^{12}$. (Figura 2)

${ }^{12}$ O Jornal O ESTADO DE SÃO PAULO, em sua edição de 25 de outubro de 1985 noticia o fato, com o cabeçalho"A inauguração da Albrás, uma festa de US\$ 1,3 milhão". 
Figura 2 - Presidente José Sarney na inauguração da Albrás (Jornal O Estado de São Paulo, 25 de outubro 1985).

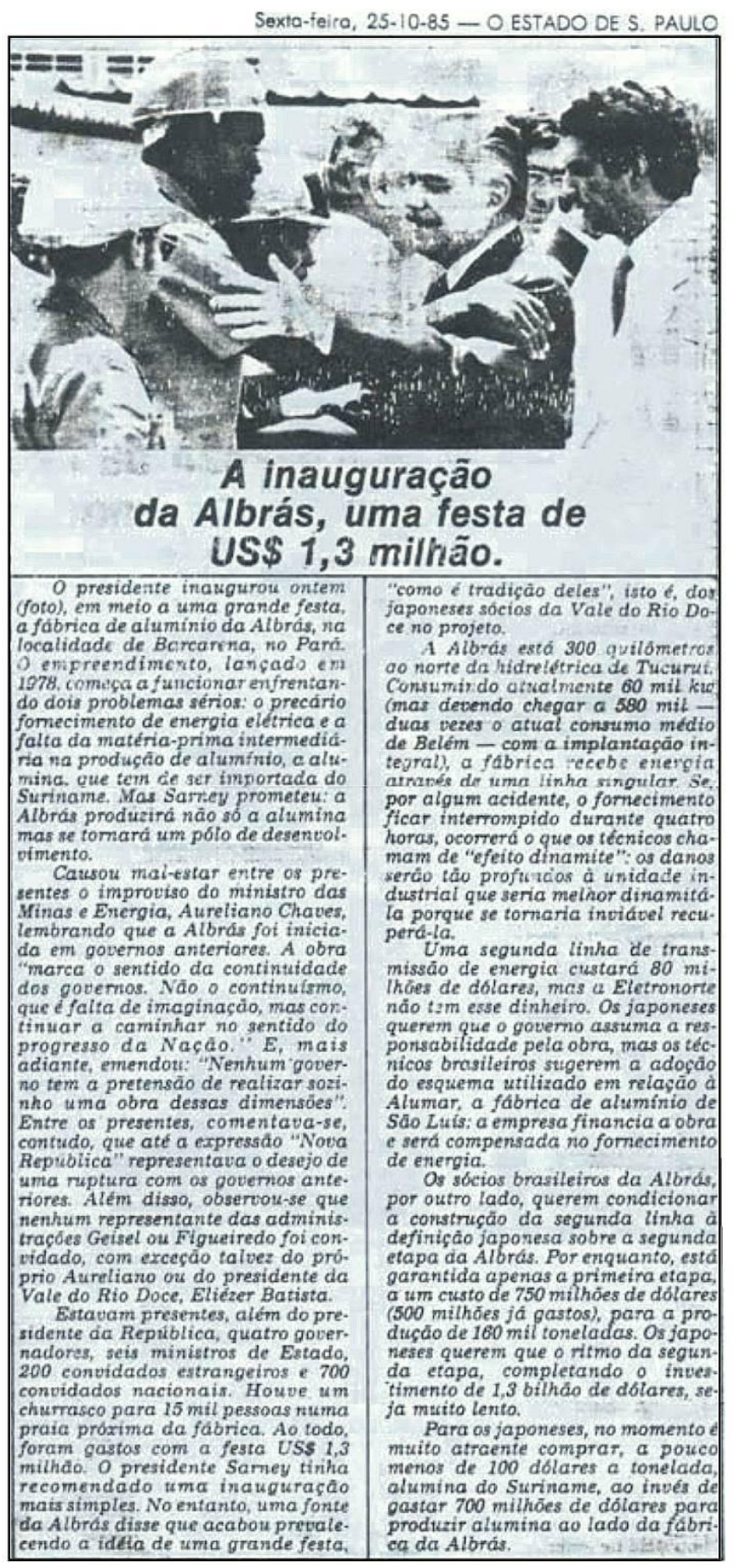

Se, naquele então (1979), o urbanista Joaquim Guedes ampliava a prática da

interdisciplinaridade, instalando equipes muito diversificadas, como cautela à difícil tarefa de "planejar", o geógrafo que eu era, havia feito sérios progressos na análise integrada da natureza sob a ação do homem, não apenas baseada nos subsídios fornecidos pela escola alemã de geografia, na análise geo-ecológica e na dinâmica de paisagens, mas fortalecido pelo 
novo paradigma dos geossistemas, propostos simultaneamente na França (G. Bertrand nos

Pirineus, França e V. Sotchava, Sibéria, URSS) a partir de $1968^{13}$. (Figuras 3 e 4).

Figura 3 - Esboço Geo-ecológico de uma micro- região de Barcarena/PA

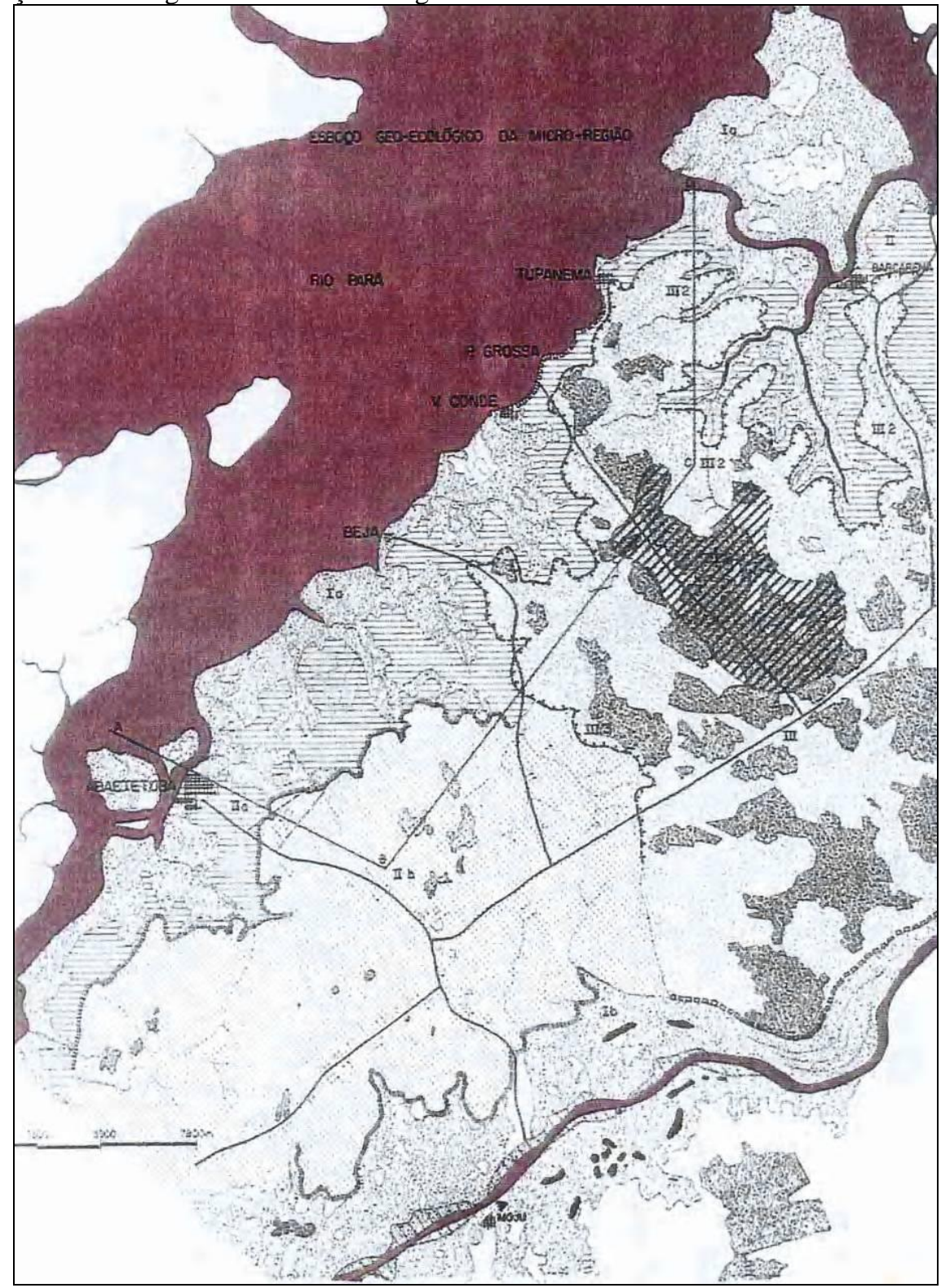

\footnotetext{
13 A evolução desse conceito e sua progressão foi por mim narrada na obra GEOSSISTEMAS - A história de
} uma procura" produzido em 1994 e lançado pela editora Contexto, de São Paulo, em 2000. 
Figura 4 - Perfil Geral de articulação de articulação regional das unidades geo-ecológicas (Barcarena/PA).

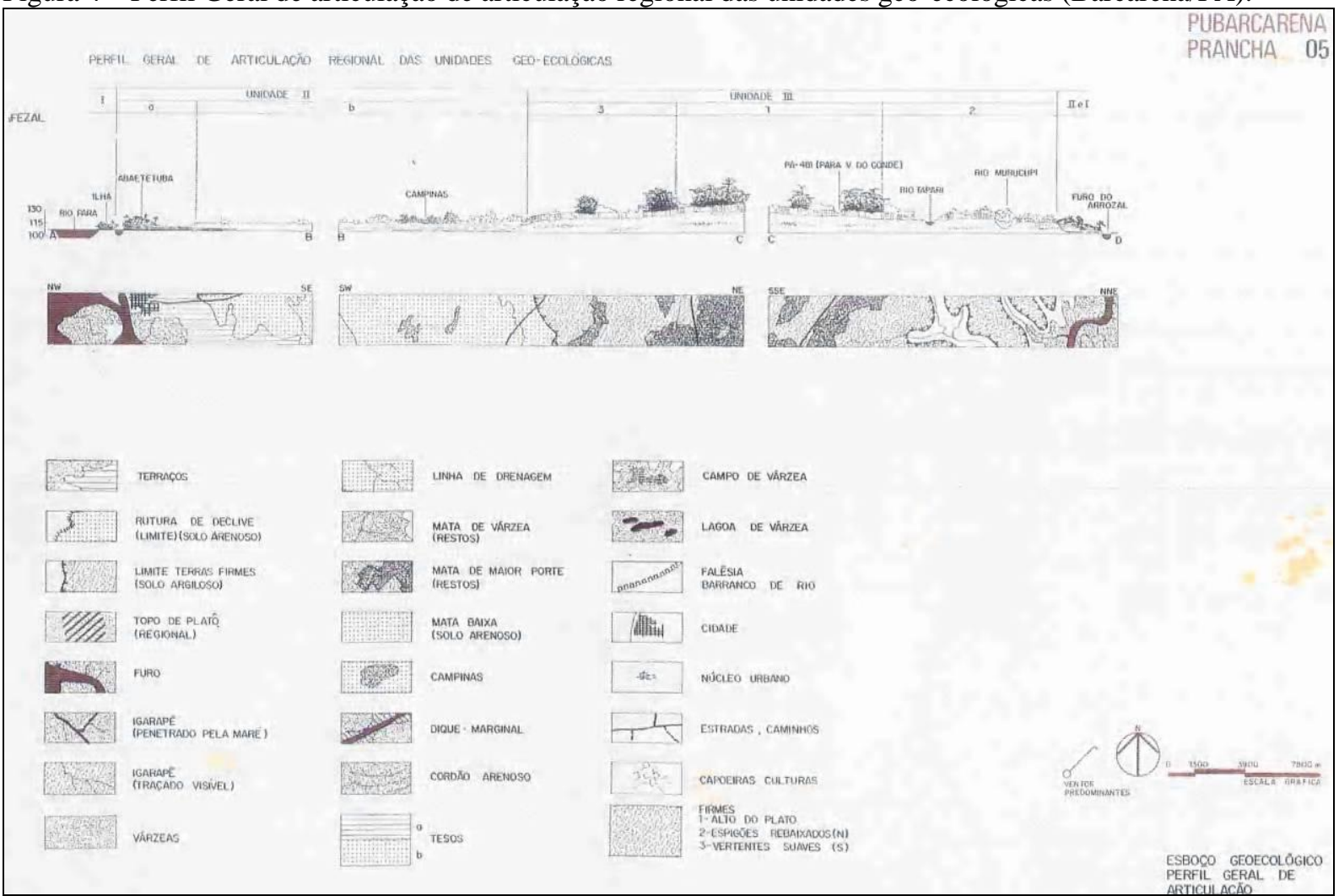

O aumento dos meus compromissos pessoais de pesquisa e de orientação nos cursos de pós-graduação em Geografia na FFCCH-USP reduziu as disponibilidades de tempo para enredarme em assessorias a outros projetos. Ficou uma boa lembrança. Barcarena passou a ser mais um volume na minha estante de obras realizadas e uma agradável lembrança.

No ano passado (2003) fui honrado com convite para participar do Congresso de SBAU (Sociedade Brasileira de Arborização Urbana) realizado em Belém do Pará. Após o evento e uma agradável excursão à ilha de Marajó (Soure) e a Manaus, retornei a Belém para assistir ao Círio de Nazaré. Lembrei-me de Barcarena e decidi que não podia perder a oportunidade de ver como estava, passados vinte e cinco anos, o núcleo urbano de cuja origem ocupáramonos em uma variada equipe.

Contratei um taxista e, recorrendo ao "ferry-boat", no dia 9 de outubro, uma Quintafeira antecedendo ao Domingo dia 12 - data do Círio - dei um apressado giro por Barcarena. Diferentemente de 1979, quando o acesso era feito por Cafezal, aportamos em Araparí, seguindo pelo taxi a Barcarena Velha, hoje a sede de um município do qual pertence o núcleo planejado - designado Bairro Jardim Cabano. Não dispondo de tempo para pernoitar e fazer uma visita demorada, limitei-me a um reconhecimento turístico muito apressado, percorrendo 
o que foi possível, fotografando aquilo que me pareceu mais significativo. Algumas poucas rápidas entrevistas com comerciantes e moradores deram-me algumas informações.

Daquela visita rápida ficou-me uma grande frustração. Aquela de desperdiçar a oportunidade preciosa de realizar uma adequada análise do problema, com observação direta no campo, inquéritos, coleta de dados nas instituições públicas (e industriais, se possível). Em termos ideais, verificar o que aquela equipe - de Joaquim Guedes e Associados - preconizava, e o que havia sido realizado da proposta original.

Um dos traços mais marcantes na proposta do desenho urbano era o aproveitamento das águas do igarapé que corta a área central do núcleo, o que seria obtido pelo represamento do mesmo, antes de sua confluência no furo da Barcarena. Creio que esse fato foi abandonado, pois no meu trajeto - que embora rápido, foi percorrido em várias direções - não me dei conta da existência do mesmo. Gostaria de saber quais as razões que levaram a seu corte.

Eu não teria a leviandade de trazer para vocês, nesse brilhante auditório, considerações aprofundadas sobre os "resultados" daquele planejamento. Mas não quero privar-me de aproveitar o ensejo para - com a ajuda de algumas transparências projetadas - apontar-lhes três pequenos tópicos que, dentre aquilo que me foi dado guardar na memória, durante o trabalho de planejamento da equipe (1979) e observado (corridamente) agora (2003). Creio com isso dar uma idéia de como a contribuição de um geógrafo, na abordagem "do meio físico" pode subsidiar o urbanista.

\section{$1^{\circ}$ Problema - A ventilação e a relação urbana entre o Residencial e o Industrial}

Recordo-me que, num dado momento das entrevistas, Guedes apontou-me o problema segundo o qual a orientação que ele pretendia dar às ruas no design a propor parecia conflitar com o que estava registrado na sucessão mensal das "rosas dos ventos" obtidas dos dados colhidos no aeroporto de Val-de-Cãs (única fonte disponível e satisfatoriamente aceitável pela proximidade entre Belém e Barcarena).

Fiz-lhe entender que o número de calmarias - registrado no centro da rosa em algarismo representativo da proporcionalidade $(\%)$ - indicava a importância zonal equatoriana na movimentação vertical, ascendente, característica e produtora dos fortes aguaceiros ocorrentes nas horas de maior aquecimento $(15,16$ horas). Devia ser notado também que as direções 
encontravam-se muito variadas e de fraca intensidade, notando-se predominância daqueles do quadrante NE. Esse fato é de significância considerável na relação entre as posições do núcleo e do distrito industrial. O bom senso indicava, assim, que ele deveria estar posicionado a SW do núcleo urbano. A orientação de ruas na direção NE-SW seria conveniente, mas não obrigatória, posto que as calmarias predominavam claramente no jogo variado da direção dos ventos. (Figura5).

Figura 5 - Circulação anual dos ventos.

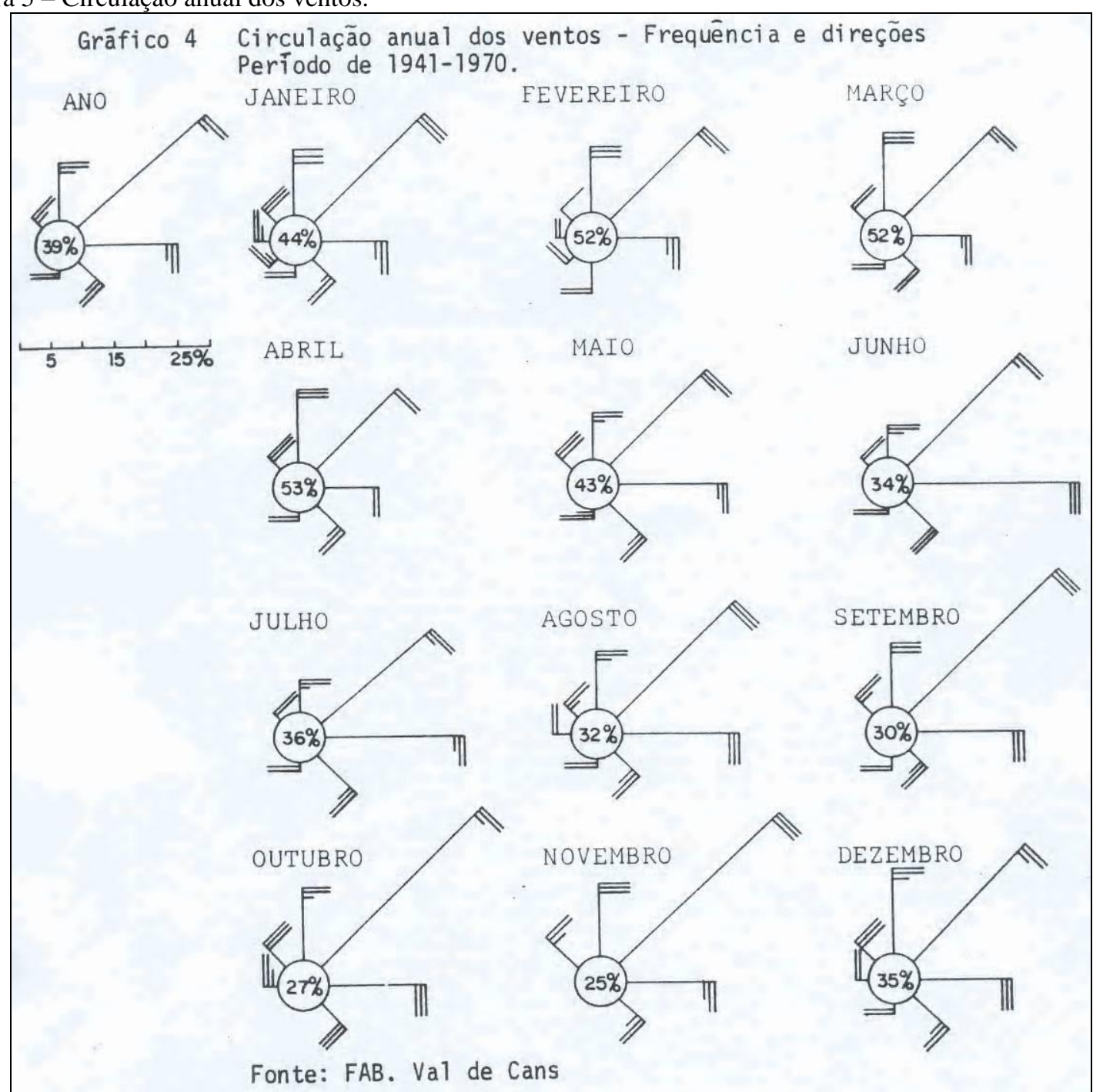




\section{$2^{\circ}$ Problema: Entre o jogo ecológico da Natureza e o desejo estético do artista criador como "demiurgo"}

Num outro momento, após a exibição que o urbanista fez do desenho urbano a ser proposto eu - com indisfarçável ar de provocação - indaguei por que enquanto a natureza amazônica usa e abusa das linhas curvas e sinuosidades, ele preferia as retas.

Como eu esperava, a resposta veio clara e com ênfase. Quando alguém sobrevoar a Amazônia com suas linhas curvas vai perceber a reta como um sinal da presença do Homem, que deseja impor-se a natureza, embora tendo o cuidado de não agredi-la seriamente. Algo como um contrariar sem danificar. Mais ou menos isto como resposta. (Figura 6).

Figura 6 - Organização Espacial da micro área.

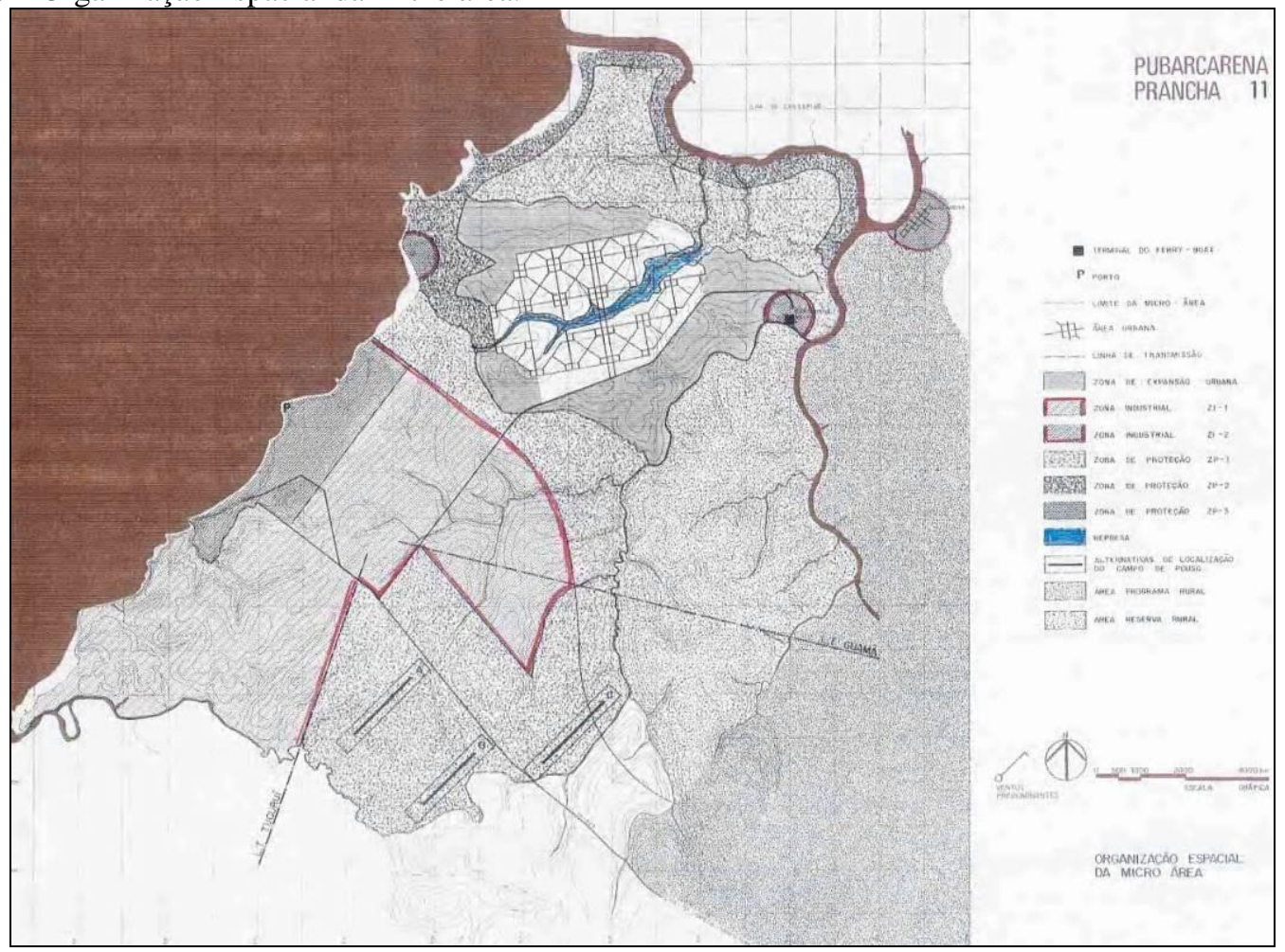

Estou entre aqueles que consideram a arte, sob todas as suas formas, uma necessidade capital e aceito a liberdade criadora do artista. Desaprovo os exageros da Ecologia Pesada. A cidade, como reflexo cultural, forçosamente terá que espelhar a criação artística. Se o estético

\footnotetext{
${ }^{14}$ Segundo PLATÃO demiurgo seria o artesão divino ou o princípio organizador do universo que, sem criar de fato a realidade, modela e organiza a matéria caótica pré-existente através da imitação de modelos eternos e perfeitos. (Definição no Dicionário HOUAISS p.935).
} 
aliar-se ao "funcional" e ambos não agredirem ou expulsarem a natureza, tanto melhor. Esta á a meta que - por mais utópica que pareça - deve nos unir.

\section{$3^{\circ}$ Problema: $O$ aproveitamento da Cobertura Vegetal no Desenho Urbano (O lugar da natureza na Cidade do Homem.}

Este caso enquadra-se perfeitamente no âmbito da SBAU e na temática do evento, servindo bem a uma visão conjunta dos variados campos de nossas especialidades, convergindo para um problema central. Pelas razões já explicadas, não se espere uma análise aprofundada do caso, mas ele poderá ser observado através de um ângulo específico, como se verá em seqüência.

A área onde os fatores conjugados aconselhavam uma combinação favorável à implantação do núcleo urbano da novíssima Barcarena, entre vantagens topográficas, edáficas, etc. dispunha de razoável cobertura vegetal com predominância de matas, num mosaico em que, num predomínio de vasta mata secundária (ou capoeira alta) encontravam-se manchas de variado tamanho de mata mais alta, sugerindo, inclusive por seu porte, um parentesco mais próximo com a mata primitiva ${ }^{15}$. (Figuras 7 e 8 )

Figura 7 - Cobertura do solo.

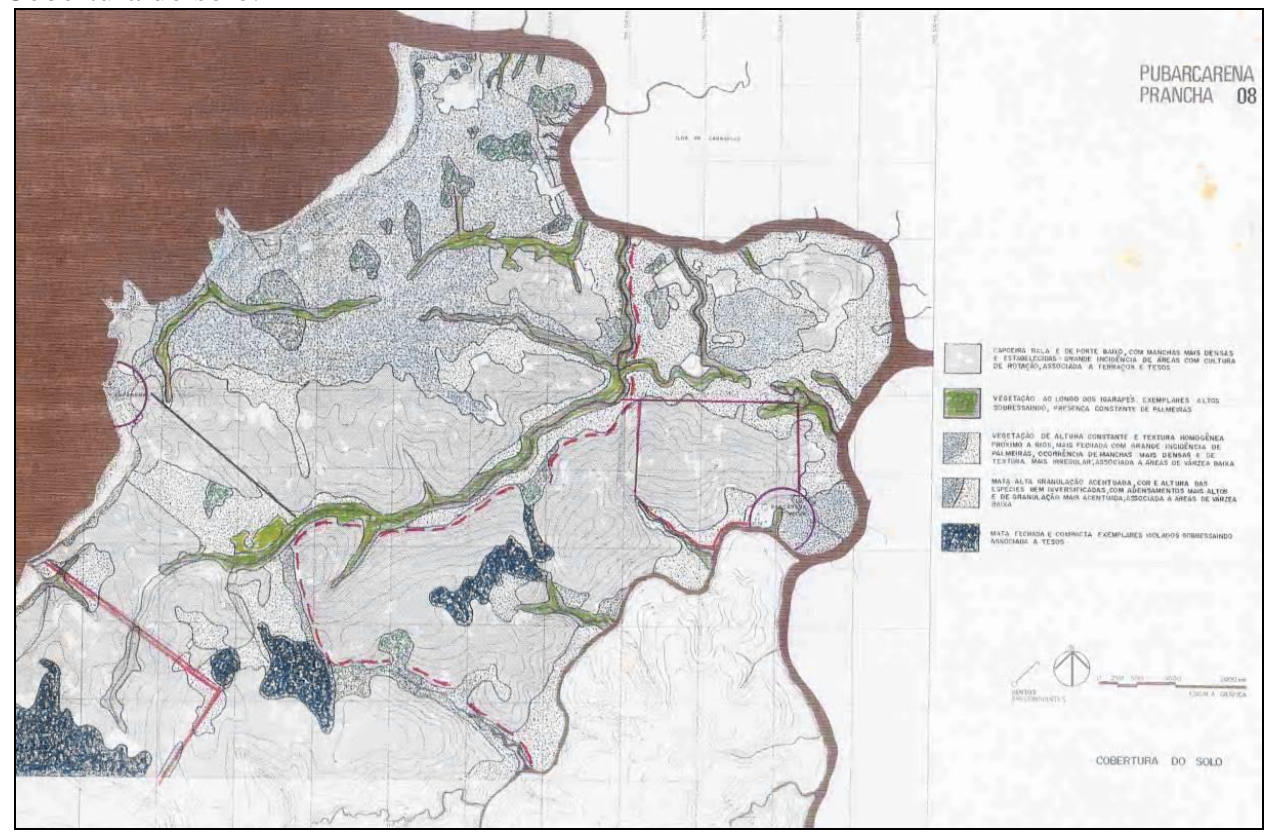

\footnotetext{
${ }^{15}$ Aproveito aqui o ensejo para assinalar a atitude dos colegas da análise botânica que, num louvável bom senso, apresentaram os resultados de sua análise em termos acessíveis ao arquiteto urbanista. A cobertura vegetal é designada em termos simples, pelo seus aspectos morfológicos mais específicos: altura das árvores, tipos predominantes, densidade, etc. em vez de usar uma terminologia complicada, dos usuais sistemas de classificação usados em botânica ou fito-geografia.
} 
Figura 8 - Cobertura do solo em perfil.

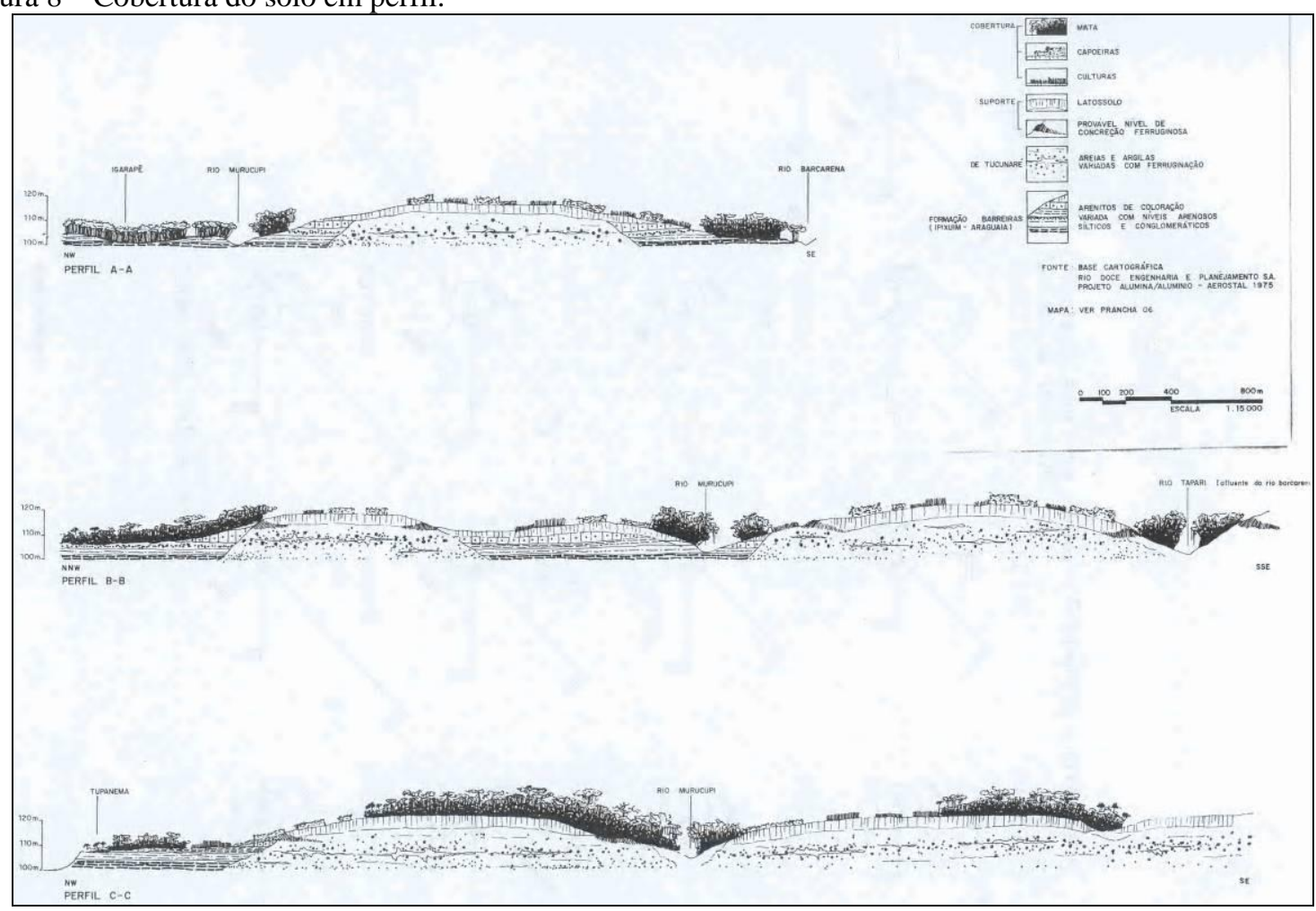

Diante das grandes questões que foram discutidas pela equipe, o aproveitamento de cobertura vegetal teve destaque. Joaquim Guedes proclamava sempre que não tencionava propor "uma cidade anti-amazônica em plena Amazônia". Mas se tratava de um problema novo, do qual não havia exemplos em que se basear. Quais seriam os requisitos mínimos para integrar a "mata" no desenho urbano? Qual seria a reação da fauna que está sempre associada à flora? Seria ela prejudicial ou incômoda aos citadinos? Em que proporções essa cobertura biótica deveria ser utilizada? Como geógrafo atraiam-me duas vantagens: a manutenção dos espaços necessários a infiltração das águas pluviais, numa região de altos índices e o papel abrandador" das altas temperaturas no jogo temperatura-umidade projetado no "conforto térmico" $" 16$.

Essa era uma das grandes curiosidades que me motivavam a ir visitar - mesmo que apressadamente - a cidade nascente (mas já com duas décadas de existência). Uma colega, engenheira agrônoma paraense, durante o Congresso da SBAU em Belém comentara comigo

\footnotetext{
${ }^{16}$ A este propósito animava-me o fato de que, dois anos antes, havia feito - em companhia de um colega algumas medidas termo-higrométricas de campo, na cidade paraense de Marabá, o que resultou na obra MONTEIRO, C.A. de Figueiredo e TARIFA, José Roberto "Contribuição ao Estudo do Clima Urbano de Marabá: uma abordagem de campo subsidiária ao Planejamento Urbano - in CLIMATOLOGIA no. 7 - São Paulo, Instituto de Geografia da USP, 1977.
} 
que - naquele problema de "incorporação" da mata ao desenho urbano, - havia-se incorrido num grave erro. Ao derrubar as árvores mais baixas para implantar as edificações, deixava as mais altas, desprotegidas do sub-bosque, caindo sobre as casas. Fiquei espantado com a notícia posto que, no trabalho de Marabá (também com Joaquim Guedes) havia ficado muito claro que, no novo sítio previsto para deslocar a cidade, anualmente invadida pelas cheias do Tocantins, haviase observado que, havendo sido derrubada a mata e deixadas as castanheiras (castanha do Pará, Bertholettia excelsa) essas grandes árvores, de raízes superficiais e desprotegidas do sub-bosque, estavam desabando.

Por mais corrida que tenha sido minha visita, as fotos que consegui sacar exibem um aparentemente bom aproveitamento de longas faixas de mata, entremeadas às largas avenidas. Os espaços residenciais "planejados" não se inserem no meio da mata. Onde o problema ocorre - o que nos foi dado constatar - está ligado aos casos de "invasões", nas quais a edificação é "espontânea", ilegal, não planejada. Aí observa-se bem que as remanescentes árvores altas, isoladas, estão prestes a cair. O que vem demonstrar mais uma vez que a qualidade ambiental nas cidades brasileiras está íntima e indissoluvelmente ligada à qualidade social. (Conjunto de fotos 1, 2, 3, 4 e 5)

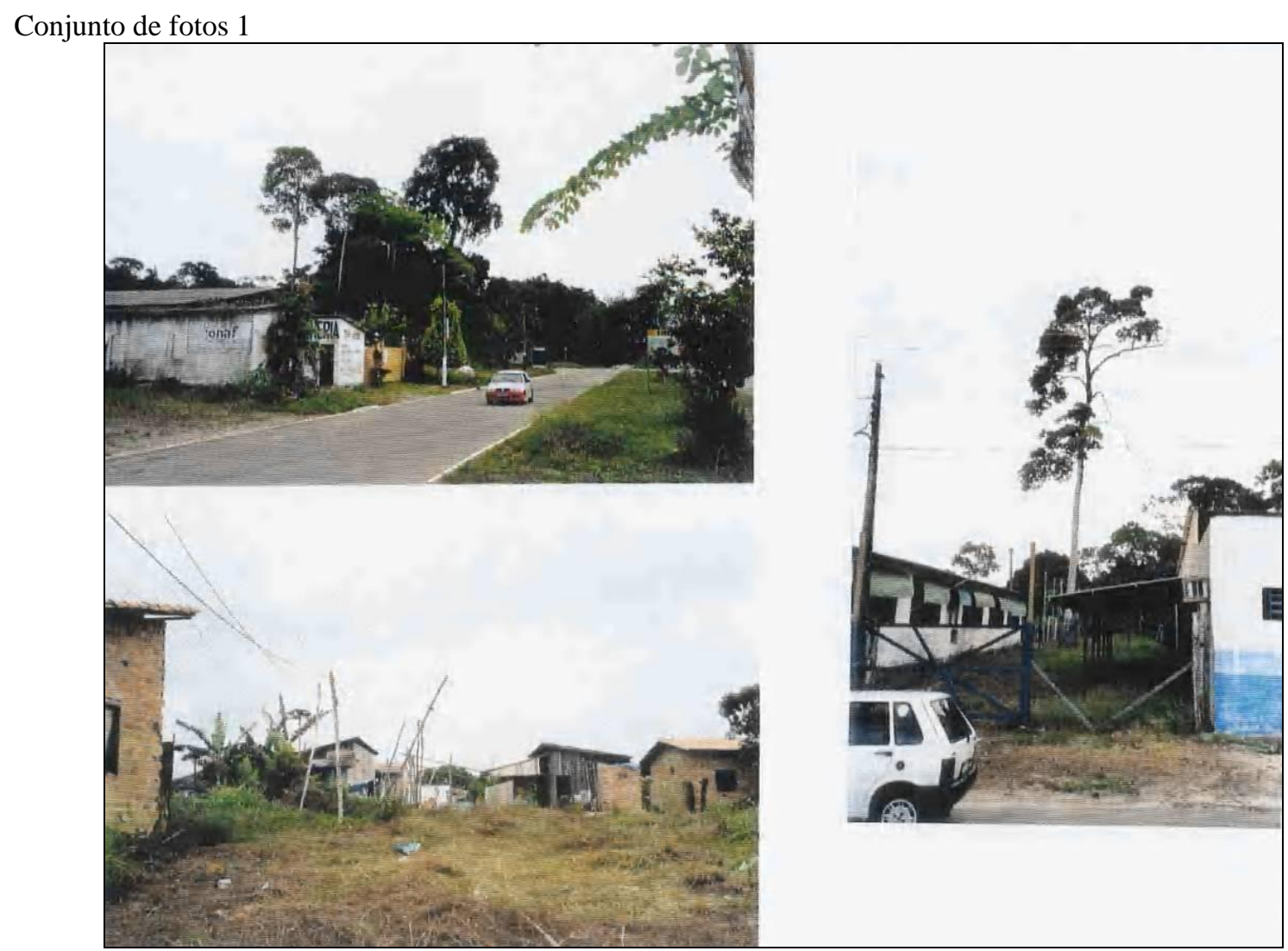


Conjunto de fotos 2

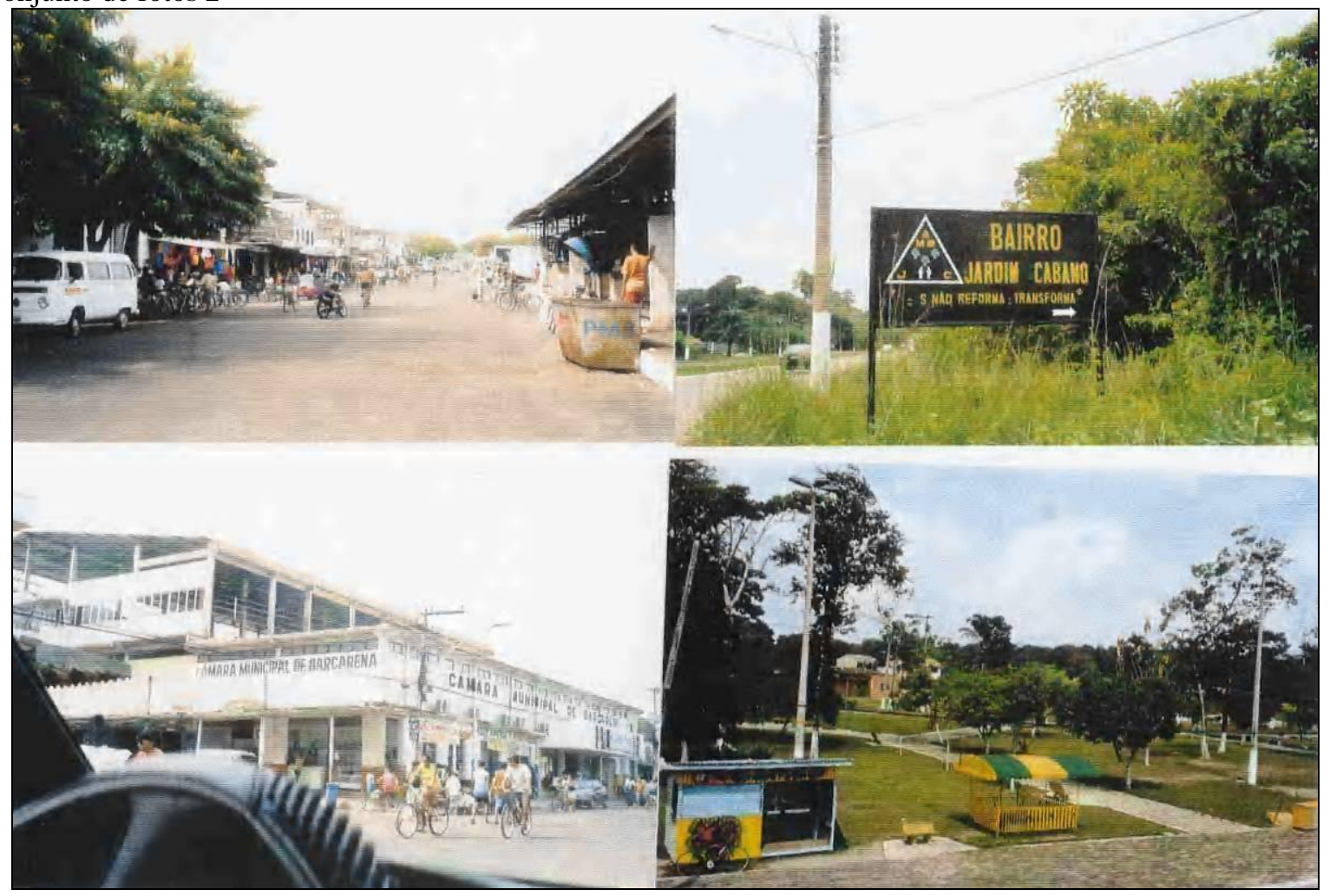

Conjunto de fotos 3

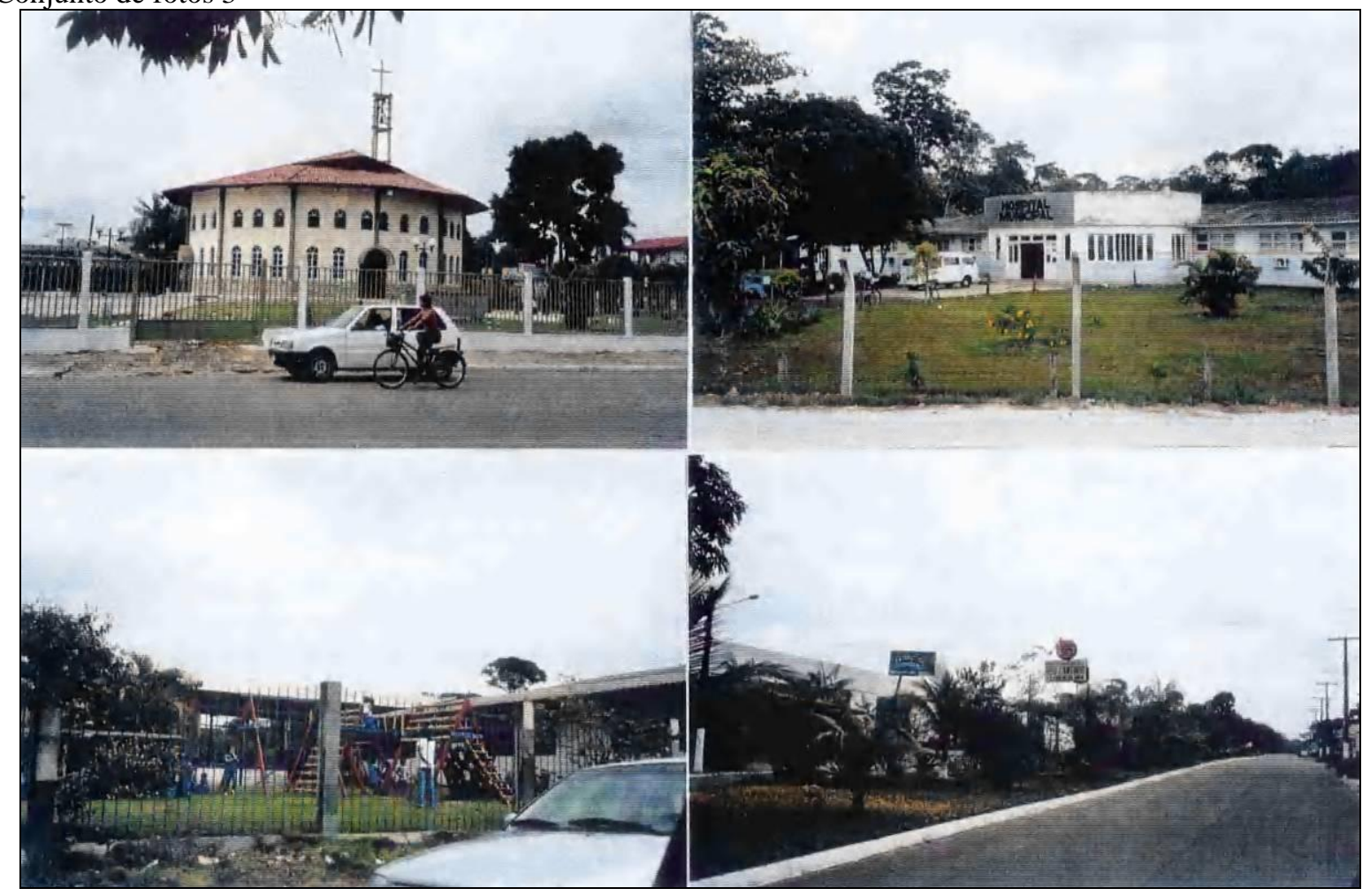


Conjunto de fotos 4

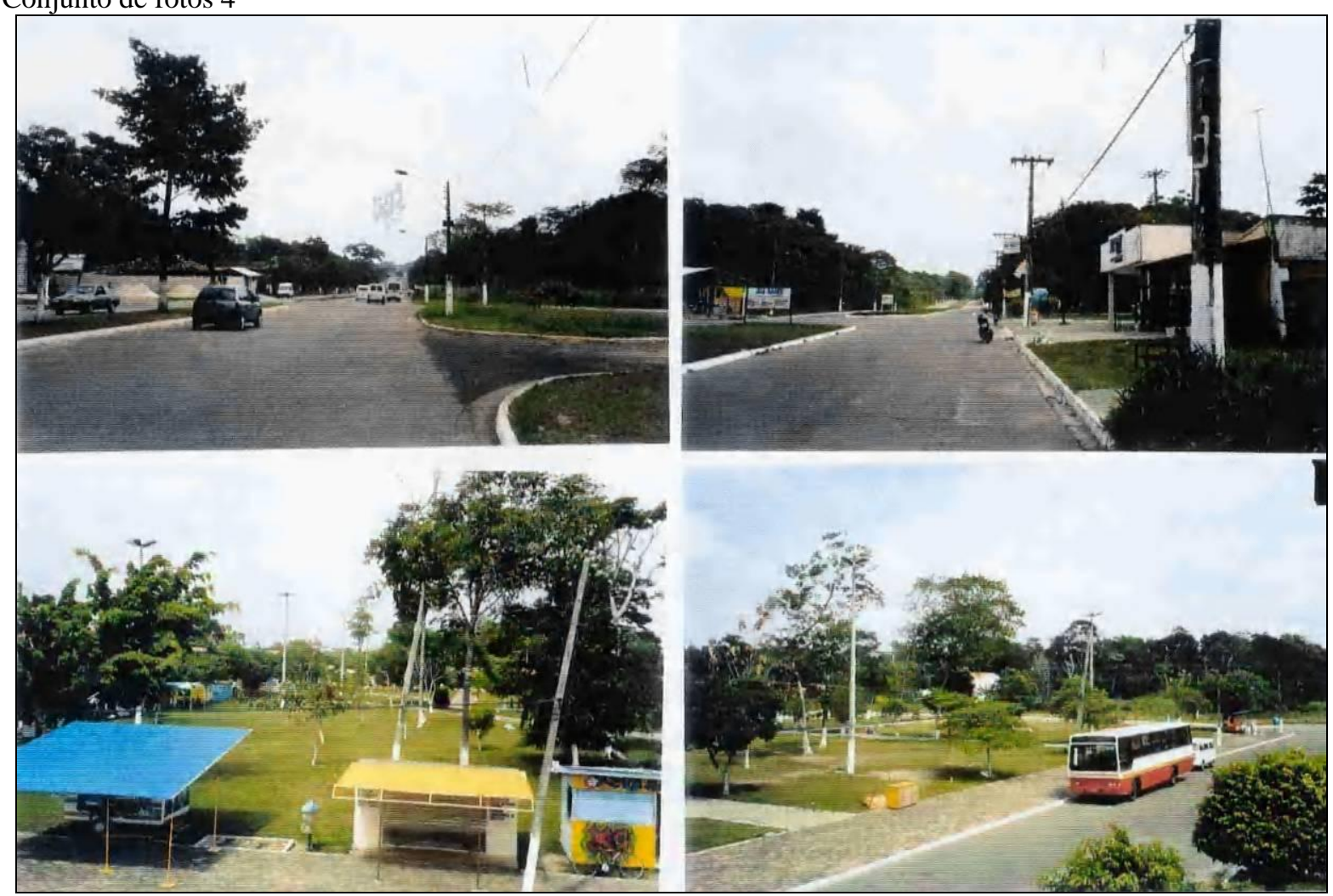

Conjunto de fotos 5

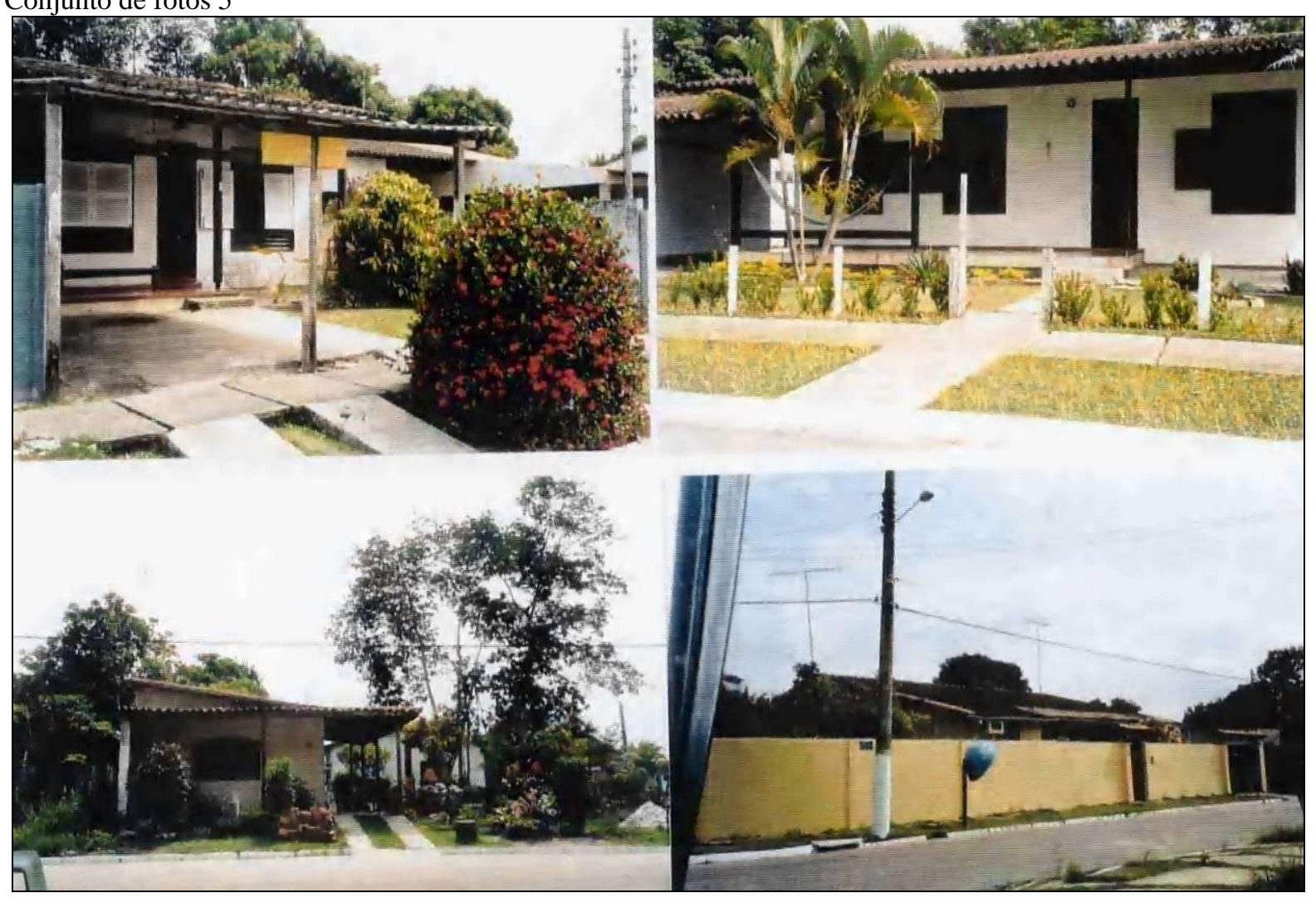


Por esta pequena (e precária) amostra, os colegas podem dar-se conta da importância que teria uma pesquisa cuidadosa sobre o destino que tem assumido aquele organismo urbano a partir do que foi para ele "planejado". Creio ser este um anseio dos planejadores urbanos, a julgar pelo caso do próprio Joaquim Guedes que, como tese ao concurso de Livre Docência na FAU-USP - no qual participei na comissão examinadora - escolheu o acompanhamento da proposta de um outro núcleo urbano implantado pela Caraíba Metais do sertão baiano, que levava o título - "Um Projeto e seus Caminhos".

\title{
ALGUMAS ILAÇÕES SOBRE O PLANEJAMENTO URBANO
}

Considerando o fato de que a organização do evento teve a boa idéia de conectar as conferências com as mesas redondas que se lhes seguem - incluindo nos debates os próprios conferencistas - ocorreu-me arrolar uma série de tópicos ou temas relevantes às discussões.

No caso específico da relação entre a consideração das componentes naturais (dito "meio físico") no processo de planejamento urbano, segundo normas tão claramente expostas pelo atual Presidente da SBAU - Arquiteto Paulo Celso Dornelles Del Picchia ${ }^{17}$, seria proveitoso dirigir esses tópicos para o tema central O VERDE E A CIDADE grupando-os em três sub-conjuntos.

Relembro as palavras do Senhor Presidente da SBAU para direcionar a minha proposta:

\begin{abstract}
"Gostaríamos que as questões ligadas à arborização urbana, à administração dos espaços livres urbanos fossem enfrentadas nos seus aspectos técnicos e científicos e pudessem sair dos meios acadêmicos para a ação prática na administração de nossas cidades, que as pesquisas e conquistas técnico-científicas viessem a se tornar realidade no planejamento, projeto, gerenciamento e administração dos espaços verdes de nossas cidades. Que o desenho urbano se valesse da noção de sustentabilidade da natureza e que a vivência da natureza e da paisagem orientasse o crescimento e as modificações urbanas respeitando os anseios das populações como participantes dessas modificações."
\end{abstract}

\section{FUNDAMENTAÇÃO POLÍTICA}

O primeiro bloco diz respeito à fundamentação política da qual emanam as normas para “a ação prática na administração de nossas cidades”. As cidades refletem fielmente o tipo de país no qual elas se inserem. Quais as diretrizes de sua formação social, do seu modelo

\footnotetext{
${ }^{17}$ Expresso no Editorial do órgão oficial de Divulgação do SBAU BOLETIM INFORMATIVO - Ano XII n ${ }^{\circ} 1$ $1^{\circ}$ semestre de 2004- São Paulo, SP. Página 1.
} 
econômico, etc. etc? A ordenação superior, nacional, nesses campos, reflete-se nas realidades urbanas que tendem para a ordem ou para o caos.

Os instrumentos legais de gestão administrativa advêm dessa base política nacional. No nosso caso é oportuno refletir sobre as grandes variações e oscilações pelos quais tem passado as diretrizes gerais dirigidas ao urbano. No presente, temos a ver com um Ministério especial, um Estatuto, aparentemente pretendendo articular a prática de $\underline{\text { Planos Diretores, a }}$ reformulação de Regiões Metropolitanas, e uma sintonização dos diferentes níveis de participação - municipal, estadual, federal atuantes (nem sempre articuladamente) na gestão urbana.

O Estatuto da Cidade, além de suas ambigüidades por vezes "surrealistas", apresenta-se em flagrante dissonância com a Constituição Federal.

Levando-se em conta esse vetor básico, parece que podemos extrair alguns pontos importantes a considerar.

1. A cidade como aglomerado humano é um fato social que se configura como a edificação de uma natureza derivada em direção a seus propósitos a elas associadas. A concepção do mundo, o sistema de valores, as aspirações que se expressam pela produção de um espaço multidimensional segundo as varias diferenças (política, econômica, social, culturais, ambientais, etc. etc.) são itens que expressam suas interações relacionais em diferentes geometrias (euclidianas, concretas, relacionais, abstratas, etc. etc.).

2. As diretrizes político-administrativas para a gestão das cidades são traçadas por categorias de políticos profissionais na disputa de poder, conduzidos por transações nem sempre credenciadas para um bom direcionamento das realidades urbanas. Daí decorre que, em termos verdadeiramente democráticos, a produção das normas por eles propostas devem ser submetidas a críticas - profissionais e acadêmicas - daqueles mais diretamente envolvidos com a realidade urbana e com a sociedade civil diretamente afetada ao viver urbano.

3. A cidade que aglomera o Homem, atraído por uma possibilidade de felicidade e

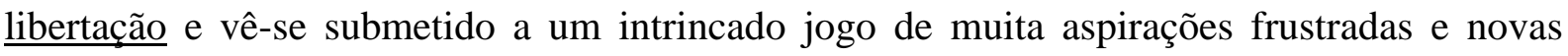
conquistas realizadas, é um fenômeno dinâmico, permanentemente em mutação. Para a "harmonia" desse complexo processo deverá prevalecer uma dinâmica evolutiva cujo sentido corresponda às aspirações dos homens (citadinos) de todas as camadas da população, não só para o hoje mas sobretudo, para o amanhã. 


\section{CRIAÇÃO URBANA}

O segundo bloco aglutina as questões básicas pertinentes à efetiva criação da cidade, ou seja, a geração daquele construto materializado que reflete a dinâmica dos processos vigentes. É claro que nos referimos à materialização (estrutura concreta - urbanismo) daquilo a que as diferentes variáveis condicionam a gênese do fato urbano (processo dinâmico - urbanização).

O primeiro passo nesse campo será aquele de enfrentar vários tabus, preconceitos, ligados à formação profissional especializada e ao espírito de cooperação dos membros da equipe planejadora. Sente-se hoje, nesta grande crise histórica que atravessamos, que há necessidade de alcançarmos uma epísteme (conhecimento) mais CONJUNTIVA. Preconizase até que a harmonização dos saberes seja oriunda de uma visão holística sugerida pelas ciências da vida, como a Biologia.

No meu depoimento, no caso de Barcarena, louvei a prática do Arquiteto Urbanista Joaquim Guedes - certamente não o único - em montar equipes interdisciplinares para subsidiar o seu trabalho. Não há nenhum desdouro em não entender de tudo. Um campo complexo como a cidade não pode ser monopólio de uma profissão. Não assenta mais o espírito de "corporação" - uma prática da Idade Média. Mas, faz-se necessário reconhecer que estamos progredindo. E os Congressos da SBAU são disso um eloqüente exemplo.

O Congresso da SBAU, no ano passado, deixou-me perceber que, em meio à variedade de profissionais irmanados no tema do verde na cidade, alguns $\underline{\text { atritos }}$ ainda podiam ser sentidos, dentre os quais uma certa "animosidade" contra arquitetos. Seria pela carteira do CREA compartilhada por engenheiros (civis, agrônomos)? A humildade de um jovem colega oriundo das Belas Artes, quase pedindo licença por ali estar. Lembremo-nos de que o paisagista nacional de projeção universal, Roberto Burle Marx, veio das Belas Artes e de que a própria Arquitetura já esteve vinculada a esta unidade universitária.

A tendência é que, com o passar do tempo, esses conflitos irão se dissipando. A complexidade do universo urbano abre-se a várias preocupações e intervenções dos mais variados campos do saber. Duas das grandes questões da nossa grande crise - irmana-se aqui: a Questão Urbana e a Questão Ambiental. No evento que nos reúne, o problema do verde na cidade junta-se àquele dos Atlas Ambientais urbanos.

Assim, deste bloco poderíamos extrair alguns tópicos básicos para discussão: 
4. Se a questão urbana é ampliada em sua complexidade pelo efeito que as derivações, inclusões, e transformações decorrentes da urbanização no meio natural, o problema urbano abre-se, cada vez mais, a um espectro pluridisciplinar que deve juntar esforços na prática interdisciplinar.

5. No caso brasileiro, é indisfarçável a sintonia que se observa entre os problemas ambientais urbanos e aqueles das desigualdades sociais, constituindo como que as duas faces de uma mesma moeda.

6. Essa junção, conjugação, de esforços possibilitará o entrosamento dos variados aportes que poderão subsidiar as difíceis diretrizes do "planejamento". A consideração das condições específicas dos processos naturais, aliada aos grandes progressos tecnológicos na engenharia - provedora de infra-estrutura - e com os progressos da arquitetura, tanto nos aspectos de novos materiais (estruturas metálicas, plásticas, concreto protendido, etc. etc.) e criação artística (novas formas possibilitadas pelas novas técnicas e novos materiais), utilização de cores; quanto àquelas soluções produzidas nos problemas sociais, pela correção das grandes desigualdades de classes, elas poderão conduzir a cidade caótica e angustiante de hoje a novas condições de bem estar. Uma cidade futura habitada por "cidadãos".

7. Considerando o caso especial do Verde na Cidade, não podemos deixar de considerar que sua importância se projeta em vários setores da realidade urbana desempenhando funções importantíssimas nos espaços urbanizados. Dentre estas, avulta a "infiltração" atenuando o escoamento pluvial (intenso nas regiões tropicais); abastecendo os lençóis freáticos e mananciais; base indispensável à fauna que lhe é peculiar. Com a variedade de coloração dos verdes entra, não só no jogo da composição estética dos espaços livres, mas possibilita pela sua influência no albedo (índice de reflexão da luz/ absorção do calor) aproveitável no jogo do conforto térmico; etc., etc., etc.

\section{RELAÇÕES CIDADE-CAMPO}

Para completar os tópicos aqui arrolados num decálogo, gostaria de fazê-lo levando em consideração algo que me parece da maior relevância a ser considerado quando se tem consciência das mudanças que os novos progressos tecnológicos poderão trazer-nos no futuro, no que diz respeito às relações cidade-campo. 
Num primeiro momento, a importância crescente da urbanização e suas significativas mudanças, ou mesmo transformações nas cidades, nos levariam a pensar que, nessa era de "globalização", teríamos que admitir que a presença do homem na Face da Terra implicará, forçosamente, na geração de uma "sociedade urbana". Contudo, diante dessas profundas mudanças impostas sobretudo pelos subsídios da ciência e tecnologia, fadadas a um maior progresso no século entrante, não será absurdo pensar ou admitir que venha ocorrer uma conseqüente modificação nas relações cidade-campo.

Incorporando tudo aquilo que foi dito a propósito do paralelo entre a cidade arcaica e a cidade atual, exibindo o triângulo "cidade-campo-natureza", cabe refletir sobre as tendências vigentes na interpretação dos modos de viver urbano e rural.

8. Diante de tais evidências nas relações cidade-campo, é o caso de nos formularmos questões tais como: Quais as possibilidades de que a cidade do futuro venha a ser organizada (planejada ou corrigida) segundo os cânones vigentes agora em plena grande crise? Se já existem evidentes sinais de interpenetração entre o urbano e o rural - a cidade espalhando-se pelo campo circundante sob a forma de condomínios fechados (complicando os limites dos primitivos urbano e rural e a cobrança do IPTU) e o rural, remetendo à cidade levas contínuas de sem-terras para tornarem-se citadinos sem-teto - não haverá possibilidade de alcançar novos termos nesse relacionamento?

9. O entrosamento entre os modos de viver na cidade e no campo implica no sério problema que a concentração (urbana) e a dispersão (rural) acarretam em termos econômicos da engenharia de infra-estrutura. Enquanto a primeira é mais conveniente do ponto de vista social e implica em menos gastos para as obras básicas, a segunda favorece as condições climáticas, ambientais resultando em ampliação considerável dos gastos com as redes de obras infra-estruturais.

10. Embora apenas apresentando tendências e vestígios não é possível negar ou afirmar as possibilidades de novos modos de vida entrosando o urbano-industrial ao ruralrecreacional. Diante de tantas mudanças, quem sabe não estaremos na soleira de um novo modo de organização dos espaços condizentes com uma "ñova civilização" que está germinando? O que não parece razoável é que, com tanto fastígio tecnológico não possamos resolver os graves problemas de uma estruturação urbana debilitante acompanhada de um sério desequilíbrio das estruturas demográficas e sociais condicionadas a um ambiente nefasto. 
Principiamos fazendo apelo ao mito de Édipo e a Utopia da Atlântida, colhidas na matriz cultural grega de nosso universo dito ocidental. Diante de tantos problemas que afetam o modo de viver do homem na face da terra no início desse terceiro milênio da era cristã, é claro que não pode ser descartada a validade da UTOPIA. Para propô-la, é indispensável uma compreensão profunda dos reais problemas, para poder projetar as possíveis soluções em outros níveis de combinações das diferentes variáveis e em outras escalas diferentes daquelas atuais. Uma projeção futura do ideal assentado na realidade do presente.

Não será tarefa fácil. Mas uma certeza que podemos ter é aquela de que sozinhos, setorialmente enquistados em corporações não conseguiremos alcançá-la. Resta-nos ampliar essa benéfica atitude que já se comprova pela realização de eventos como o que aqui nos aproxima nesses Congressos da SBAU: irmanados, solidários, promovendo a real prática da interdisciplinaridade.

São Paulo, 14 de Setembro de 2004.

(Recebido em setembro/08. Aceito em outubro/08) 